\title{
GFAP and S100B Protein are Associated With Discharged NIHSS of Anterior Circulation Ischemic Stroke
}

\author{
Yenny Surjawan ${ }^{1,2 *}$, Suryani As'ad ${ }^{1}$, Teguh A.S. Ranakusuma ${ }^{3}$, Andi Wijaya ${ }^{1,2}$ \\ ${ }^{1}$ Post Graduate Program in Clinical Biochemistry, Hasanuddin University, Jl. Perintis Kemerdekaan Km.10. Makassar, Indonesia \\ ${ }^{2}$ Prodia Clinical Laboratory, National Refrence Lab., Prodia Tower 2nd fl., Jl. Kramat Raya No. 150, Jakarta, Indonesia \\ ${ }^{3}$ Faculty of Medicine, University of Indonesia, Jl. Salemba Raya No.6, Jakarta, Indonesia \\ *Correspondence: e-mail: yensurjawan@yahoo.com
}

\section{Abstract}

$\mathrm{B}$ ACKGROUND: Patient with larger ischemic lesion will suffer more severe neurological deficit. The utility of MRI for lesion size measurement is still limited, therefore additional approach was pursued through examination of markers released by damaged brain cell, GFAP and S100B protein. The aim of this study is to know whether both markers are associated with the neurological deficit of anterior circulation ischemic stroke.

METHODS: This observational prospective study enrolled 74 patients with anterior circulation ischemic stroke diagnosis. GFAP and S100B protein were measured with ELISA using blood collected at 48 to 72 hours after onset. The neurological deficit was assessed with NIHSS at discharge.

RESULTS: There was a significant association between GFAP level and discharged NIHSS ( $p=0.008)$ with $100 \%$ sensitivity and $100 \%$ negative predictive value. S100B protein also showed a significant correlation with discharged NIHSS $(r=0.488 ; p=0.000)$ and this correlation could be described with an equation $(\mathrm{OR}=$ $1.009 ; 95 \%$ CI $1.0003-1.0188 ; \mathrm{p}=0.044)$. S100B protein at $78.3215 \mathrm{ng} / \mathrm{l}$ would give true prediction as $73.9 \%$ (95 $\%$ CI $62.7 \%-85.2 \%, \mathrm{p}=0.001$ ).

\section{Abstrak}

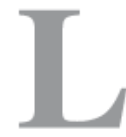

ATAR BELAKANG: Pasien stroke iskemik dengan lesi yang lebih luas biasanya akan mengalami defisit neurologis yang lebih berat. Pengukuran luas lesi dengan MRI masih terbatas penggunaannya, oleh karena itu diupayakan suatu pendekatan lain melalui pemeriksaan protein S100B dan GFAP yang merupakan petanda kerusakan sel otak. Tujuan penelitian ini untuk mengetahui apakah kedua petanda tersebut berhubungan dengan beratnya defisit neurologis pada pasien stroke iskemik sirkulasi anterior.

METODA: Studi observasional dengan pendekatan prospektif ini dilakukan terhadap 74 pasien dengan diagnosis sebagai stroke iskemik sirkulasi anterior. GFAP dan protein S100B diperiksa dengan metode ELISA menggunakan darah yang diambil pada jam ke 48-72 jam setelah onset. Beratnya defisit neurologis dinilai melalui pemeriksaan skor NIHSS saat pulang.

HASIL: GFAP menunjukkan hubungan yang bermakna dengan NIHSS saat pulang $(\mathrm{p}=0.008)$ dengan nilai sensitivitas sebesar $100 \%$ dan nilai prediksi negatif sebesar $100 \%$. Protein S100B juga menunjukkan korelasi yang bermakna dengan NIHSS saat pulang $(r=0.488 ; p=$ 0.000 ) dan korelasi ini dapat digambarkan melalui suatu 
CONCLUSION: GFAP and S100B protein that were measured at 48 to 72 hours after onset were significantly associated with NIHSS at discharge.

KEYWORDS: GFAP, S100B protein, discharged NIHSS, ischemic stroke

Indones Biomed J 2012; 4 (2): 112-117 persamaan $(\mathrm{OR}=1.009 ; 95 \%$ CI $1.003-1.0188 ; \mathrm{p}=$ 0.044 ). Pada kadar $78.3215 \mathrm{ng} / \mathrm{l}$, protein S100B dapat memprediksi $73.9 \%$ kasus secara benar (95\% CI 62.7 $85.2 ; \mathrm{p}=0.001)$.

KESIMPULAN: GFAP dan protein S100B yang diukur pada jam ke 48-72 jam setelah onset menunjukkan hubungan bermakna dengan NIHSS saat pulang.

KATA KUNCI: GFAP, S100B protein, NIHSS saat pulang, stroke iskemik

Indones Biomed J 2012; 4 (2): 112-117

\section{Introduction}

Based on Indonesian Health Profile 2008, stroke still ranks as the first cause of death in Indonesian (1). Stroke patients who survived generally suffered a disability. Most of post stroke patients will have sequelae with varying degrees of severity (2).

The severity of stroke is commonly determined by the location and the size of the ischemic lesion $(2,3)$. In several studies, larger lesion which is associated with worse outcome was reported to have a higher concentration of glial fibrillary acidic protein (GFAP) and S100B protein $(4,5,6,7)$. The aim of this study is to know whether GFAP and S100B protein are associated with the discharged National Institute of Health Stroke Scale (NIHSS) after anterior circulation ischemic stroke.

\section{Methods}

It is an observational study with a prospective design performed on 74 anterior circulation ischemic stroke patients who came to the hospital not more than 72 hours after the onset. Subjects were enrolled from several hospitals in Jakarta and Makassar since June 2011 until May 2012. The diagnosis of anterior circulation ischemic stroke was made by neurologist based on the data of anamnesis, physical examination, and proved with CT or
MRI. Either single or multiple infarct was included in this study. This study was approved by the Health Research Ethics Committee, Medical Faculty of Hasanuddin University, Makassar, Indonesia.

Stroke subjects who had a first attack and received a standard medical care were included in this study. Patients who had liver dysfunction (female: AST $>54 \mathrm{U} / \mathrm{L}$, ALT $>68 \mathrm{U} / \mathrm{L}$; male: AST > $66 \mathrm{U} / \mathrm{L}$, ALT $>100 \mathrm{U} / \mathrm{L}$ ), serum creatinine $>1.6 \mathrm{mg} / \mathrm{dl}[141.44 \mu \mathrm{mol} / \mathrm{L}]$, random blood glucose $<55 \mathrm{mg} / \mathrm{dl}[3.0525 \mathrm{mmol} / \mathrm{L}]$, systolic blood pressure $<100 \mathrm{mmHg}$ or diastolic blood pressure $<70$ $\mathrm{mmHg}$, and history of cancer, acute myocardial infarction, or congestive heart disease within the last 3 months were excluded from this study.

Blood was collected between 48 to 72 hours after the onset of stroke. Serum for GFAP and S100B protein measurement were kept at $<20^{\circ} \mathrm{C}$ until all samples were ready to be analyzed and the diagnosis of anterior circulation ischemic stroke was confirmed. The concentration of GFAP was measured with ELISA method using Human GFAP ELISA RD reagent from Biovendor (Cat. RD 192072200R) and the result was reported in ng/ ml. S100B protein was measured with ELISA method using CanAg S100BB EIA from Fujirebio (Cat. 70810) and the result was reported in $n g / l$. The assays were performed at Research Department of Prodia Clinical Laboratory, Jakarta, Indonesia.

Stroke outcome was recorded when the patient was discharged from hospital. Patients who survived were assessed for their NIHSS by a trained assistant or neurologist. The results were noted with the range from 0 as the minimal score to 42 as the maximal score. The NIHSS was classified as mild, moderate and severe 
if the score was less than 4,4 to 15 , and more than 15 , respectively. Non survive patients were considered to have the maximum score of NIHSS.

Data was analysed using SPSS 13.0 statistical analysis software for Windows (SPSS Inc., Chicago, IL, USA). The significant level of this analysis was set at $5 \%$.

Table 1. Subject's baseline characteristics $(\mathrm{N}=74)$

\begin{tabular}{|c|c|}
\hline Variable & $\mathbf{N}(\%)$ \\
\hline \multicolumn{2}{|l|}{ Onset (hours) } \\
\hline$<24$ & 68 (91.9) \\
\hline$>24$ & $6(8.1)$ \\
\hline \multicolumn{2}{|l|}{ Age (years old) } \\
\hline $33-52$ & $23(31.1)$ \\
\hline $53-63$ & $32(43.2)$ \\
\hline $64-79$ & $19(25.7)$ \\
\hline \multicolumn{2}{|l|}{ Gender } \\
\hline Male & $45(60.8)$ \\
\hline Female & $29(39.2)$ \\
\hline \multicolumn{2}{|l|}{ Admission NIHSS } \\
\hline Mild $(0-3)$ & $15(20.3)$ \\
\hline Moderate $(4-15)$ & $58(78.4)$ \\
\hline Severe $(16-42)$ & $1(1.4)$ \\
\hline \multicolumn{2}{|l|}{ Discharged NIHSS* } \\
\hline Mild $(0-3)$ & $30(40.5)$ \\
\hline Moderate $(4-15)$ & $42(56.8)$ \\
\hline Severe $(16-42)$ & $2(2.7)$ \\
\hline \multicolumn{2}{|l|}{ NIHSS progression } \\
\hline Better & $49(66.2)$ \\
\hline Stable & $21(28.4)$ \\
\hline Worse & $4(5.4)$ \\
\hline \multicolumn{2}{|l|}{ Status at discharge } \\
\hline Survive & $72(97.3)$ \\
\hline Non survive & $2(2.7)$ \\
\hline \multicolumn{2}{|l|}{ GFAP level (ng/ml) } \\
\hline Low $(<0.2500)$ & $67(90.5)$ \\
\hline High $(>0.2500)$ & $7(9.5)$ \\
\hline \multicolumn{2}{|c|}{ S100B protein concentration $(\mathrm{ng} / \mathrm{l})^{*}$} \\
\hline Q1: $51.58(33.02-57.79)$ & $20(27.0)$ \\
\hline Q2: $67.11(61.52-77.70)$ & $16(21.6)$ \\
\hline Q3: $90.18(78.95-110.23)$ & $20(27.0)$ \\
\hline Q4: $265.27(148.04-2553.08)$ & $18(24.3)$ \\
\hline
\end{tabular}

\section{Results}

Data analysis was performed on 74 subjects with anterior circulation ischemic stroke diagnosis. The baseline characteristics of these subjects were shown in Table 1 . Most of these subjects were admitted to hospital within 24 hours after onset and had moderate admission NIHSS $(78.4 \%)$. At discharge from hospital there were 4 subjects (5.4\%) with severe NIHSS and 2 of them died, while almost all of the remaining subjects showed improvement in their NIHSS (66.2\%).

The concentration of S100B protein ranged from 33.02 to $2553.08 \mathrm{ng} / \mathrm{l}$. The median and the minimal to maximal concentration of each quartiles of S100B protein were shown in Table 1. The level of GFAP were classified as low if the concentration of GFAP was less than the lowest value of calibrator $(<0.2500 \mathrm{ng} / \mathrm{ml})$ and high if the concentration was greater or equal to the lowest value of calibrator $(\geq 0.2500 \mathrm{ng} / \mathrm{ml})$.

There was a significant difference in the proportion of subjects with low GFAP and high GFAP in either non severe or severe group of NIHSS at discharge (Fisher's exact test, $\mathrm{p}=0.008$ ) (Table 2). The assay of GFAP showed a sensitivity of $100 \%$ (95\% CI $15.8-100 \%$ ) and specificity of $93.1 \%$ ( $95 \%$ CI $84.5-97.7 \%)$ with positive predictive value of $28.6 \%$ (95\% CI $3.7-71.0 \%)$ and negative predictive value of $100 \%$ (95\% CI 94.6-100).

Table 2. Crosstab between GFAP level and status of NIHSS at discharge

\begin{tabular}{|c|c|c|c|}
\hline \multicolumn{4}{|c|}{ Severe discharged NIHSS } \\
\hline & Yes & No & Total \\
\hline High GFAP & 2 & 5 & 7 \\
\hline Low GFAP & 0 & 67 & 67 \\
\hline Total & 2 & 72 & \\
\hline
\end{tabular}


The concentration of S100B protein was significantly different among NIHSS groups (Kruskal Wallis test, $\mathrm{p}=$ 0.001). Further post hoc analysis using Mann Whitney test revealed a significant difference of S100B protein concentration between subjects with mild and moderate discharged NIHSS $(\mathrm{p}=0.001)$, and also between mild and severe discharged NIHSS $(\mathrm{p}=0.024)$. The median concentration of $\mathrm{S} 100 \mathrm{~B}$ protein in the severe group was higher than the median concentration in the moderate group, but the difference was not significant $(\mathrm{p}=0.055)$ (Figure 1).

Spearman correlation test showed that there was a significant correlation between S100B protein and discharged NIHSS $(r=0.488 ; p=0.000)$. The probability to get a non mild discharged NIHSS by S100B protein concentration might be predicted from an equation $(\mathrm{p}=$ $\left.1 /\left\{1+2.7^{6.30-0.009 \times \text { s } 100 \text { p protein }}\right\}\right)$ with $\mathrm{OR}=1.009 ; 95 \% \mathrm{CI}$ $1.0003-1.0188(\mathrm{p}=0.044)$.

The discrimination ability of this equation was checked with receiver operating characteristics (ROC) (Figure 2) that produced an area under curve (AUC) of $73.9 \%$ ( $\mathrm{p}=0.001,95 \%$ CI $62.7 \%-85.2 \%$ ). The cutoff value of S100B protein at $78.3215 \mathrm{ng} / \mathrm{l}$ produced a sensitivity of $66 \%$ and specificity of $70 \%$, with positive predictive value and negative predictive value of $76 \%$ and $58 \%$, respectively.

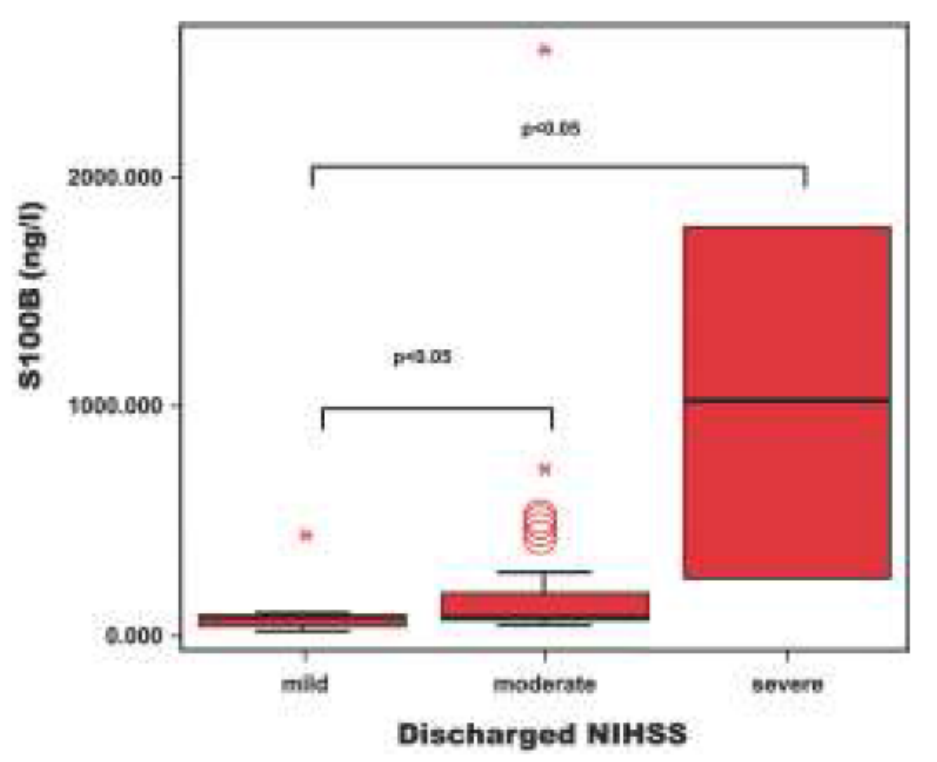

Figure 1. $\mathrm{S} 100 \mathrm{~B}$ protein concentration in mild, moderate, and severe discharged NIHSS.

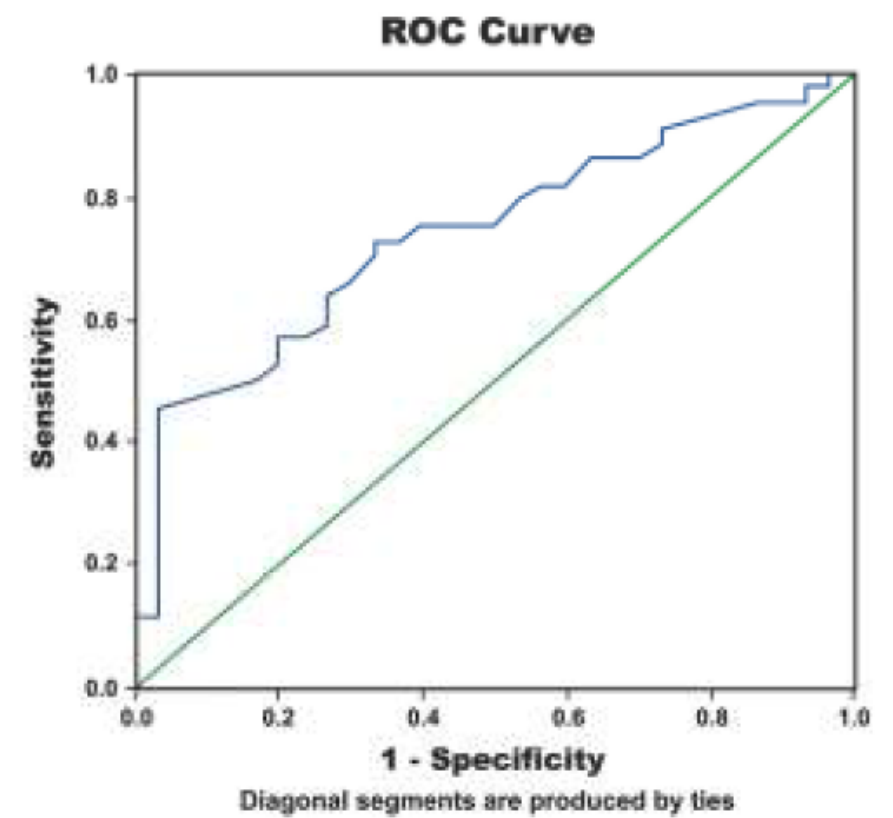

Figure 2. ROC curve of S100B protein to discriminate discharged NIHSS. 


\section{Discussion}

In ischemic stroke, the cerebral blood flow is disturbed because of the obstruction of cerebral blood vessel. Energy that is required for normal brain metabolism is reduced and the ischemic brain cells are unable to control the passage of ions through cell membranes. The ions imbalance will trigger a sequential biochemical reaction (ischemic cascade) until finally the brain cells disintegrate and die (8).

The disintegration of brain cell membranes will cause the GFAP known as the cytoskeleton of astrocyte and the S100B protein located in the cytoplasmic of astrocytes, to be released into the cerebrospinal fluid $(9,10)$. The markers of the brain damage will leak to systemic circulation as the blood brain barrier is also disrupted (11).

A previous study by Herrmann et al., showed that GFAP level had a correlation with both lesion size $(\mathrm{r}=$ $0.955, \mathrm{p}<0.0001)$ and NIHSS $(\mathrm{r}=0.717, \mathrm{p}=0.0003)$ (12). In our study, GFAP level showed a significant association with discharged NIHSS $(\mathrm{p}=0.008)$. All patients with severe discharged NIHSS showed high GFAP level. No patients with low GFAP level had severe discharged NIHSS. Based on this high sensitivity and negative predictive value, the low level of GFAP might be considered as an indicator to exclude the possibility to get a severe NIHSS at discharge.

There were only 2 of 7 subjects with high level of GFAP $(0.2870$ and $13.7590 \mathrm{ng} / \mathrm{ml})$ who were discharged with severe NIHSS, but both of these patients were die. High GFAP might be associated with mortality.

S100B protein also showed a positive significant correlation with discharged NIHSS $(r=0.488 ; p=0.000)$. Patients with higher concentration of S100B protein would be discharged from hospital with higher NIHSS. This was in accordance with the result previous study that showed a correlation of S100B protein concentration with lesion size $(r=0.957, \mathrm{p}<0.0001)$ and neurological deficit measured by NIHSS. The strongest correlation of S100B protein and NIHSS was found when the patient was discharged from hospital $(r=0.821, p=0.0002)(12)$.

A significant difference of $\mathrm{S} 100 \mathrm{~B}$ protein concentration was found between mild and non mild (moderate and severe) discharged NIHSS $(\mathrm{p}<0.05)$. The probability to get a non mild discharged NIHSS could be predicted by S100B. Alhough the OR in this study was only 1.009 , it could give a significant estimation of how big the risk and probability to get a not mild discharged

\section{Table 4. The risk and probability to get a non mild discharged NIHSS based on $\mathrm{S} 100 \mathrm{~B}$ protein}

\begin{tabular}{lcc}
\hline S100B protein $(\mathbf{n g} / \mathbf{l})$ & Risk & Probability (\%) \\
\hline 1 & 1.009 & 0.18 \\
50 & 1.57 & 0.28 \\
100 & 2.46 & 0.45 \\
500 & 90.2 & 14.19 \\
1000 & 8103.08 & 93.70 \\
1500 & 729416.37 & 99.92 \\
2000 & 65659969.14 & 100 \\
2500 & 5910522063.02 & 100 \\
\hline
\end{tabular}

NIHSS by S100B concentration as illustrated in Table 4. This due to the S100B protein concentration in this study had a quite large range (33.02-2553.08 ng/l). The true prediction of the equation was $73.9 \%$. The patient would have a non mild discharged NIHSS if they had S100B protein concentration greater than or equal to $78.3215 \mathrm{ng} / 1$ ( $\mathrm{p}=0.001,95 \%$ CI $62.7 \%-85.2 \%$ ). This assay showed a sensitivity of $66 \%$ and specificity of $70 \%$ with $76 \%$ positive predictive value and $58 \%$ negative predictive value.

In addition to lesion size, the severity of neurological deficit is also influenced by the location of ischemic stroke (8). Our study tried to limit this influence by selecting subjects whose lesion were in anterior circulation area. But, this was still a pitfall of this study because the large lesion in frontal will do much better than the very small lesion at internal capsul, whereas both are distribuded by anterior circulation (8).

The association of GFAP and S100B protein with discharged NIHSS in this study needs to be validated before it can be utilized. More significant prediction might be obtained if the result of S100B protein and GFAP is combined with other known clinical variables that influence the outcome of stroke (multivariable predictor) $(4,13)$.

\section{Acknowledgement:}

We thank Prodia Education and Research Institute for funding this research. 


\section{References:}

1. Indonesian Health Profile 2008. Jakarta: Ministry of Health, Republic of Indonesia; 2010.

2. Parham, S. New biomarkers could deliver a strike at stroke: Feature Story. CAP Today. 2004 November.

3. Whiteley W, Tseng MC, Sandercock P. Blood biomarker in the diagnosis of ischemic stroke: A systematic review. Stroke 2008;39:2902-9.

4. Whiteley W, Wei LC, Sengupta A, Sandercock P. Blood markers for the prognosis of ischemic stroke: a systematic review. Stroke 2009;40:e380-9.

5. Buttner T, Weyers S, Postert T, Sprengelmeyer R, Kuhn W. S-100 protein: serum marker of focal brain damage after ischemic territorial MCA infarction. Stroke 1997;28:19615.

6. Missler U, Wiesmann M, Wittmann G, Magerkurth $O$ Hagenstrom $\mathrm{H}$. Measurement of glial fibrillary acidic protein in human blood: analytical method and preliminary clinical results. Clin Chem 1999;45:138-41.
7. Wunderlich, MT, Ebert $A D$, Kratz $T$, Goertler M, Jost $S$, Herrmann M. Early neurobehavioral outcome after stroke is related to release of neurobiochemical markers of brain damage. Stroke 1999;30:1190-5.

8. Caplan LR. Caplan's Stroke: A Clinical Approach. 4th ed. Philadelphia: Saunders; 2009.

9. Michetti F, Gazzolo D. S100B Protein in biological fluids: a tool for perinatal medicine. Clin Chem 2002;48:2097-104.

10. Herrmann M, Vos P, Wunderlich MT, de Bruijn CHMM, Lamers KJB. Release of glial tissue-specific proteins after acute stroke: a comparative analysis of serum concentration of protein S-100B and glial fibrillary acidic protein. Stroke 2000;31:2670-7.

11. Hill MD. Diagnostic biomarkers for stroke: a stroke neurologist's perspective. Clin Chem 2005;51:2001-2.

12. Foerch C, Curdt I, Yan B, Dvorak F, Hermans M, Berkefeld J, et al. Serum glial fibrillary acidic protein as a biomarker for intracerebral haemorrhage in patients with acute stroke. J. Neurol. Neurosurg. Psychiatry 2006;77:181-4.

13. Maas MB, Furie KL. Molecular biomarkers in stroke diagnosis and prognosis. Biomark Med 2009;3:363-83. 